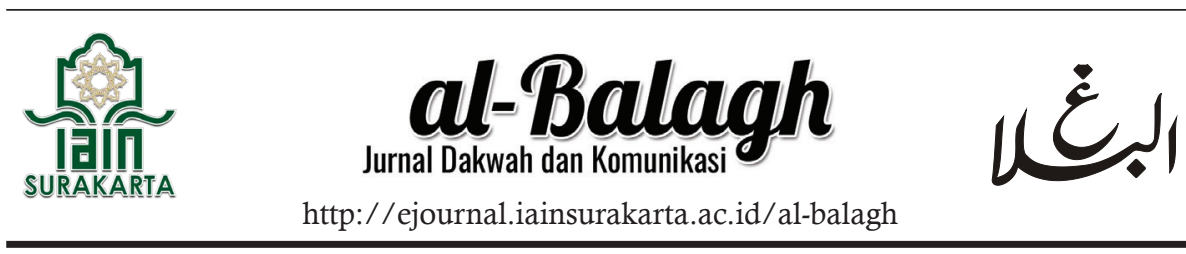

\title{
POLITICAL PROPAGANDA, MASS MOBILIZATION, AND NARRATIVE OF HABIB RIZIEQ SHIHAB IN THE AKBAR 212 REUNION
}

\author{
Ilham Fariq Maulana* \\ Universitas Indonesia, Jakarta
}

\begin{tabular}{l}
\hline \\
\hline Keywords: \\
dramatism; \\
dramatistic pentad; \\
Great Reunion \\
212; Habib Rizieq \\
Shihab; theory of \\
propaganda \\
\hline
\end{tabular}

\section{Abstract}

This study conducted a study of the rhetorical text of Habib Rizieq Shihab's (HRS) speech at the 212 Grand Reunion in 2019. This research was trying to map the elements of rhetorical motive construction through Burke's Pentadic analysis. However, this research also found gaps in political propaganda by figures and religious groups' leaders with Propaganda Theory. This interpretive research includes five contents of the HRS speech. This study's main conclusion shows that the rhetorical motive is aimed at agent and agency elements that show gaps in political propaganda in mass mobilization nationally and sympathy for HRS religious leaders and acceptance of ideas and ideas in agency elements apolitical political emotions.

Kata kunci:
dramatisme;
pentad dramatistic;
Reuni Akbar
212; Habib
Rizieq Shihab;
teori propaganda

\section{Abstrak}

Penelitian ini melakukan kajian teks dari retorika sambutan Habib Rizieq Shihab (HRS) dalam Reuni Akbar 212 tahun 2019. Tidak hanya mencoba memetakan elemen-elemen konstruksi motif retorika di dalamnya melalui analisis Pentadik Burke, penelitian ini juga menemukan celah propaganda politik yang dilakukan figur pemimpin kelompok agama dengan Teori Propaganda. Penelitian interpretif ini meliputi kelima isi amanat pidato sambutan HRS. Kesimpulan utama dari penelitian ini menunjukkan motif retorika ditujukan pada elemen agent dan agency yang menunjukkan celah propaganda

Correspondence:

e-mail: *gilham63@gmail.com 
politik dalam mobilisasi massa secara nasional dan pencuatan simpati terhadap figur pemimpin agama HRS serta penerimaan gagasan dan ide yang terdapat dalam elemen agency melalui politik emosi secara apolitis.

\section{How to cite this (APA 7th Edition):}

Maulana, I. F. (2020). Political Propaganda, Mass Mobilization, And Narrative Of Habib Rizieq Shihab In The Akbar 212 Reunion. Al-Balagh: Jurnal Dakwah Dan Komunikasi, 5(2), 251-294. https://doi.org/10.22515/ al-balagh.v5i2.2327

\section{INTRODUCTION}

The 212 Alumni Brotherhood (PA) held the 212 Grand Reunion on Monday, December 2, 2019, and is planning to return Habib Rizieq Shihab (HRS) to his homeland(Maya, 2019; Prayoga, 2019). HRS's return was called banned and had become a trending topic on Twitter social media(Meidinata, 2019). The participants returned only to find remarks and speeches from HRS who were still in Saudi Arabia via video conference recordings ahead of the day of the grand reunion. HRS conveyed several points aimed at the 212 Grand Reunion participants who had entered their third year through these remarks and speeches.

HRS mentioned several points that were highlighted in his speech. First, HRS apologized for not attending the reunion due to a ban from the Saudi Arabian government (Herlambang, 2019). Second, HRS gave five mandates for the participants of the 212 Grand Reunion, namely asking all followers to maintain the tradition of the 212 Grand Reunion; do not give up in the struggle for justice; trusting Allah's promise; asking to keep fighting; not to stop in defending religion, nation, and state(Herlambang, 2019). Third, HRS again touched on the problem of Basuki Tjahaja Purnama (Ahok) in the 2016 DKI Jakarta Pilkada and his claim of victory 
over the previous DKI Jakarta Pilkada(Herlambang, 2019). Fourth, asking his people to continue to defend their religion by judging religious blasphemers. At this point, HRS tends to lead to the recitation of the controversial poem Rachmawati Soekarnoputri(Herlambang, 2019).

Islamic mass organizations (mass organizations) in Indonesia have increasingly gained a place in Indonesia's political field (Nastiti \& Ratri, 2018). One of the prominent incidents in Indonesia related to Islamic mass organizations in the political realm is the emergence of cases of blasphemy or blasphemy during the DKI Jakarta Governor Election (Pilgub) in late 2016 and early 2017 (East \& Miichi, 2019; Marshall, 2017, 2018; Nawab et al., 2019; Power, 2018).

A series of demonstrations marked the incident held several times shortly, triggered by blasphemy allegations by the former Governor of DKI Jakarta, Ahok, in the 2016 DKI Jakarta election campaign (Marshall, 2018). The anti-Ahok movement also emerged at the same time as the Islamic Defense Action, which began in October 2016 which was organized by groups such as the Islamic Defenders Front (FPI), Hizbut Tahrir Indonesia (HTI), the National Movement for Fatwa Guards-the Indonesian Ulema Council (GNPF-MUI), and Islamic Community Forum (FUI) (East \& Miichi, 2019; Nawab et al., 2019).

The Defend Islam Action, which was carried out by several Islamic organizations, asked Ahok's participation in the election to be canceled and demanded that Ahok be prosecuted legally (Marshall, 2017; Nawab et al., 2019; Power, 2018). A number of large-scale Islamic Defense Actions took place in stages starting on 4 November 2016 (Action 411) located in Central Jakarta and culminating in a more extensive action on 2 December 2016 (212 Action), which was not only located in Jakarta but also in Jakarta. A number of other areas with an estimated 50,000 to 200,000 people took to the streets to take action (Nawab et al., 2019). 
The most significant action resulted in a politically motivated movement driven by religious interests known as the "212 Alumni Brotherhood" (IPAC Dalam Power, 2018). Ahok was eventually sentenced to two years in prison on May 9, 2017 (Marshall, 2017). PA 212 annually holds the 212 Grand Reunion on December 2 to commemorate the "victory" in the Islamic Defense Movement and Action. The association of groups in PA 212 then sparked Habib Rizieq Shihab from FPI as the high priest, Sabri Lubis, the leader of FPI, and Bachtiar Nasir, the leader of the GNPF-MUI (Nawab et al., 2019).

This group's existence in the perspective of identity originally appeared to fight against the religious blasphemy committed by Ahok in 2016. However, when viewed from a deeper perspective, it will be seen that there are several different motivations from one element of society to another who are members of this group. Qadir and Wildan in Burhani (2016) mentioned that some reasons made the community join PA 212 , among them the concern that they would be seen as defenders of blasphemy because they did not want to be left behind by the "mass flow train," seeing this movement as a festival, ideological motivations, to the political interests of the election at that time. Some opinions from various elements of society and observers can be collected, such that this group from PA 212 is not purely a movement driven by religious dogma alone. However, there are political interests from several parties behind it.

Several legal practitioners and legal and human rights watchdog groups such as Human Rights Watch (HRW) also assessed that the blasphemy article could become a rubber article. The implication is given by this article that has existed since 1968 often ends up being an article for political purposes (Vit \& Erlangga, 2016). However, nothing as serious has been done in the Ahok case. HRW sees the form of the case that befell Ahok as a manifestation of the "rubber article" of article 156a of the Criminal Code concerning blasphemy (Vit \& Erlangga, 2016). 
HRW also added that the public ignored significant problems regarding these articles' use due to the increasing frequency of ensnaring various public figures and figures who mostly came from minority religions in Indonesia (Vit \& Erlangga, 2016). It is also considered contrary to a democratic country's concept, especially regarding freedom of opinion in the public or public sphere. Besides, there is a view that the political unrest in the 2016 DKI Jakarta Pilkada is not only due to religious fanaticism or racism accompanied by political motives. However, it became a momentum to fight back against Ahok's marginalizing the lower middle class (Vit \& Erlangga, 2016).

Several previous studies are used as references, namely research that analyzes rhetoric through drama, face-to-face, and mediated messages (films and media coverage). Such as research conducted by Murphy \& Harris (2018). The article written by Murphy \& Harris conducted a dramatic pentad analysis in the film The Help. The study was showing how the tendency of the narrative to be hierarchical that whites become agents (white saviors) to liberate blacks who indirectly show the moral form of whites (Agency), which ultimately displays the purpose of the white savior's presence (Murphy \& Harris, 2018). The study concluded that, although storylines involving black characters perpetuated stigmatized tropes, white characters were raised to a higher standard (Murphy \& Harris, 2018). They are presented as an unattainable norm that all other groups should aspire to (Murphy \& Harris, 2018).

Next, Canel \& Gurrionero's article (2016) analyzes the news texts and speeches of politicians about the bombing incident at Madrid Airport, Spain. This research presents two theories, namely Robert Entman's Media Framing and Dramatic Theory. The purpose of this study is to find an explanatory relationship from Entman's four-dimensional framing analysis with Burke's pentad ratio in a case study of speech motifs from two political camps and how the media in Spain makes news framing of 
the speech (Canel \& Gurrionero, 2016 ). This study found a relationship between Dramatic theory and framing analysis because Dramaticism adds insight into the speaker's motives, who then framing creates a bridge from the gap that appears between the social and human knowledge approaches.

Subsequent articles by Cholid, Choiriyati, \& Al Khazim (2019), the study conducted a pentad analysis from the results of documentation and text in television media regarding speeches or rhetoric delivered by the Presidential Candidate for the 2019 Election, Prabowo Subianto. This analysis looks at mediated communication (mediated communication). The results of the analysis of this study found how Prabowo's figure as an agent used the rhetoric of state conditions which he considered under threat, which was then linked to the context of the location where Prabowo delivered his speech in Semarang, Central Java, to increase the target voters at that location (Cholid et al., 2019).

Further articles courtesy of Tsikata (2019), who analyzed the accusations of Yahya Jammeh, the president of the Gambia that considered Western countries using antiretroviral drugs (ARVs) for PLWHA (people living with HIV / AIDS) (as a tool of exploitation of the African people (Tsikata, 2019). This article attempts to interrogate the rhetorical motives, the sociocultural context in Jammeh's rhetoric, and to speculate on the impact of Jammeh's rhetoric (Tsikata, 2019). The results of the analysis of this study found scapegoating actions, the spread of fear of colonialism and neo-colonialism, and calls for the meaning of health and healing from elements bound up in Jammeh's rhetoric (Tsikata, 2019). As a result, Jammeh's rhetorical strategy led to identifying Gambian people living side by side with HIV / AIDS, encouraging Gambians to take herbal remedies, temporarily avoiding ARVs from PLHIV but failing to build confidence in the country in the long term (Tsikata, 2019).

Previous research shows several things that can be criticisms of the Theory of Dramaticism. Theory of Dramaticism can be synthesized with 
other theories in qualitatively expanding studies in the rhetorical tradition. This means that this theory can use different theories to analyze the speaker's rhetoric more deeply and bridge the research question gap. This is based on the view that this theory is less clear and too complicated in explaining human experience using symbolic interactionism (West \& Turner, 2017). This study will combine or synthesize other research analysis approaches, namely the Propaganda Theory proposed by Harold D. Lasswell. Lasswell explained that propaganda manages collective attitudes by manipulating important symbols (Lasswell, 1927). The word attitude here is defined as a tendency to act according to a particular pattern of assessment. The perspective in this explanation is represented as an activity or conversation for a specific group activity (Lasswell, 1927).

Some studies related to FPI and Alumni 212 previously analyzed the impact of these organizations' existence, which are considered foster intolerance in Indonesia. Such research conducted by Gabriel Facal (2020) called FPI one of the main actors in the political and moral intermediary process. FPI places itself in the public sphere, channels political support, and takes advantage of comprehensive media coverage (Facal, 2020). While avoiding providing direct opposition to the ruling government and its constitution, this organization promotes the social morals followed by a large part of the population

It encourages radicalism and acts of violence in the name of Islam (Facal, 2020). This study conducted a literature review or literature study on FPI and other Islamic organizations and was divided into several discussions. It can be concluded that the formation is showed the stronger porosity at national borders, democratization, and liberalization processes, which supports organizations' semi-institutionalization. The institutionalization has contributed to the legitimacy of the FPI discourse (Facal, 2020). This institutionalization provides FPI members with the possibility to combine the references of Islamic law, Indonesian national 
rights, and a puritanical moral order that includes local cultural authorities to justify violent operations against minorities (Facal, 2020).

Research conducted by Widiyanto (2017)threatens, or causes injury', and it is worth asserting that 'injury may be corporal, written, or verbal'(Hall 2013: 364 argued that the idea underlying the establishment of the Islamic Defenders Front (FPI) was the idea of 'ruling good and forbidding evil' (al-amr bi al-ma'ruf was al-Nabyan al-Munkar) (Widiyanto, 2017)threatens, or causes injury', and it is worth asserting that 'injury may be corporal, written, or verbal'(Hall 2013: 364. The founders of the FPI (especially HRS) thought that the Indonesian government was silent about the incidents of crimes that occurred. Therefore, they felt the need to 'govern the good and forbid crime' by taking the necessary actions to stop crime in Indonesian society (Widiyanto, 2017)threatens, or causes injury', and it is worth asserting that 'injury may be corporal, written, or verbal'(Hall 2013: 364. This research focuses on some research questions, including how HRS justifies violence in Islamic doctrine and the national constitution?; What agency does HRS use to convey its idea of 'enjoining good and forbidding evil' socio-political factors surround HRS's thinking about violence?

The study concluded that after 2002 there were indications that the FPI had expanded the definition of crime (Widiyanto, 2017)threatens, or causes injury', and it is worth asserting that 'injury may be corporal, written, or verbal'(Hall 2013: 364. Crime is related to alcoholic beverages, gambling, prostitution, and heretical sects such as the Ahmadiyya and groups that undermine Islam, such as the Liberal Islam Network (JIL) (Widiyanto, 2017). HRS's classification as 'commendable and shameful violence' is comparable to the idea of 'legitimate and illegal violence' (Widiyanto, 2017)threatens, or causes injury', and it is worth asserting that 'injury may be corporal, written, or verbal'(Hall 2013: 364. The source of the legitimacy of HRS is from the shari'ah rules. HRS is aware that there 258 
are rules in the Qur'an and Hadith that advocate violence, but there are also rules that advocate tolerance and a more lenient approach. HRS will not take one and leave the other, but consider both (Widiyanto, 2017) threatens, or causes injury', and it is worth asserting that 'injury may be corporal, written, or verbal'(Hall 2013: 364. HRS believes that al-amr bi al-ma'ruf wa al-naby 'an al-munkar is mandatory for Muslims. The argument is based on Islamic jurisprudence principles (ushul al-fiqh) (Widiyanto, 2017)threatens, or causes injury', and it is worth asserting that 'injury may be corporal, written, or verbal'(Hall 2013: 364.

Further research on FPI focused on the politicization of religion and democracy in Indonesia, conducted by Hasan (2019)spirit for displaying religious symbols, especially Islamic symbols, into public sphere in Indonesia was getting stronger. In certain contexts, such a spirit has morphed into a political movement, or what is commonly referred to as populism. The most actual populist movement that has attracted attention of many in Indonesia recently can be found in Aksi Bela Islam (the Islam Defense Action. This study aims to analyze the politicization of religion in Indonesia according to populism theory. The results showed that religious populism in Indonesia could be seen from two sides. The populism side is seen as a result of social inequality in both national and global contexts. On the other hand, it is a threat to the future of consolidating democracy in Indonesia because of its exclusive nature, anti-multiculturalism and anti-pluralism, so that it can create a tyranny of the majority over minority rights (Hasan, 2019)spirit for displaying religious symbols, especially Islamic symbols, into public sphere in Indonesia was getting stronger. In certain contexts, such a spirit has morphed into a political movement, or what is commonly referred to as populism. The most actual populist movement that has attracted attention of many in Indonesia recently can be found in Aksi Bela Islam (the Islam Defense Action. 
Subsequent research describes post-Islamism and Islamism's study to show the position of this research in Islamic studies. Research conducted by Mojahedi (2016)as opposed to monist (or hegemonic presents a critical assessment of the post-Islamized role in Islam's discourse of tolerance. This begins with a critical review of post-Islamism and its position on pluralism and tolerance. It contextualizes the post-Islamism discourse on the broader context of post-secular criticism of modernity and theoretical debates about pluralist tolerance as opposed to monist (or hegemonic) tolerance. Post-Islamism will be criticized for losing its pluralist tolerance point (Mojahedi, 2016)as opposed to monist (or hegemonic. This research criticizes three things about post-Islamism discourse, namely about tolerance, because it fails the point of pluralist tolerance. As a result, it is confused with monist and hegemonic tolerance, the extreme submission to culturalism in understanding the dynamics of political transformation, and unconditional belief in the "secularization thesis" (Mojahedi, 2016)as opposed to monist (or hegemonic.

The results of the presentation of previous research indicate that no research tries to see the motives and constructs of rhetorical Dramaticism of religious figures accompanied by the interests of political propaganda in Indonesia with a Burkedian perspective and Propaganda Theory. This study will focus on describing how the construction of motives is built with the possibility of political propaganda dramaticism contained in the rhetoric of Habib Rizieq Shihab's five mandates at the 212 Grand Reunion in 2019. The author sees gaps in the rhetoric carried out by HRS not only to give a mandate to Alumni 212, but there is also the construction of political motives and the strengthening of group primordialism by mass mobilization through religious doctrine.

This research aims to contribute to the interpretive study of the rhetorical tradition of symbolic communication in religious groups in the Indonesian political sector. How is the construction of political propaganda 260 
motives through analysis of rhetorical texts of HRS religious figures? This is done by studying these rhetorical elements using the Pentad Analysis method described by Propaganda Theory in The Fine Art of Propaganda (Lee \& Lee, 1939).

West \& Turner (2017) see Dramaticism creating gaps in rhetorical criticism and analyzing the speaker's motives by identifying and testing the elements in them. The focus of criticism was also placed on the acting performances of its various players. So that the Theory of Dramaticism can be said to present a method in understanding the communication relationship between the text and the audience of the text, meanwhile, the Propaganda Theory which is synthesized with Dramaticism can be a method to find the context of rhetorical messages aimed at influencing public opinion on a value system without seeing the need for physical closeness to several systematic stimuli (Lasswell, 1927). Based on the social context previously described, this research will use the Theory of Dramaticism, which Kenneth Burke put forward in the early 1950s. This theory was developed and much influenced by Shakespeare's rhetoric and Aristotle (Hartelius, 2008). Griffin also stated that Burke is a literary critic who uses literary expressions and criticism in his theory (Griffin, 2012).

West \& Turner (2017) explain the metaphor of 'drama' in Burke's theory into three reasons and basic ideas of Dramaticism. First, the drama indicates a range of human experience. Second, there are several types of drama genres that are similar to the communication in human life. Third, the drama is heard closer to the audience, which shows the involvement of the audience. In brief, this theory's principle uses humans as subjects in its study; Burke stated that human observation is implicit in the terms it uses in defining humans (Suparno, 2011). Burke places humans as symbols using animal or "animals" which use symbols in this theory (Griffin, 2012). According to him, humans' animal nature and the symbols used motivate humans to do something, and language is emphasized as the most 
important symbol system (Griffin, 2012). In addition, humans' symbols show reflection, representation, selection, and deflection (bending) in reality (Suparno, 2011).

This theory views that words are the most important actions that become symbolic actions in making a drama (Griffin, 2012). So that the basic assumptions of this theory can be described as language and symbols are important systems for humans (Burke, 1968); humans are animals that wear symbols (Brummet, 1995); humans are animals that make choices (Conrad \& Macom, 1995).

The previous description explains dramatic problems that pay attention to sources, limitations, and paradoxes in using certain symbols, especially concerning the motives that occur in the act of communication (Burke, 1968). Miller (2002) views pentad analysis as a method of analysis in observing events in human life. Miller saw five aspects in human life used to understand the types of individuals behaving and communicating in their symbolic world (Miller, 2002).

The dramatic pentad offers a way to determine why each individual is in a case or context in selecting a communication strategy (Suparno, 2011). Griffin sees that the statement emphasizes one element related to four other elements. It also shows a specific context, so this analysis method can reveal the communicator's motives or views as a whole (Griffin, 2012). Pentad helps researchers map how to identify elements by assessing relationships or comparisons of each part pentad (Griffin, 2012).

The dramatic pentad elements can be translated into five elements, including act, scene, agent, agency, and purpose. First, a scene or scene is a concept that becomes the background for drama (Griffin, 2012). Agent, action, and agency have an impact on the scene that happens (Griffin, 2012). This element uses the concept of materialism, which explains if all the facts that exist are something that can be explained using the 
assumption that matter or the body is immortal, cannot be penetrated, and is relatively easy to change (Suparno, 2011).

Second, Act is the most important element in a dramatic pentad where without action there can be no drama (Griffin, 2012). The action or act element shows the motivation for action that comes from motives (Suparno, 2011). Fergusson (in Suparno, 2011) sees the action elements of two things, namely the speaker's character and thoughts. Third, Agent or agent in Griffin's view is the perpetrator or person who performs the action. So the term agent itself refers to individuals who can place personal trinkets which include ideas, desires, fears, envy, intuition, imagination, and personal expression (Suparno, 2011).

Fourth, Agency or agency is described by Burke as an instrument used by humans in achieving their goals (Suparno, 2011). So it can be said that this element is a function of the goals achieved (Suparno, 2011). Griffin explains if agency is the procedure for how the action is carried out by the agent (Griffin, 2012). Fifth, Purpose or purpose is something that is present behind the action that refers to the agent's motive (Griffin, 2012). In addition, the intended purpose is the main goal that drives an action (Harter \& Japp in Tsikata, 2019).

Furthermore, in Miles' view (Tsikata, 2019), the pentad elements do not work in isolation but rather like different parts of the organization. The pentad elements complement each other, interdependently informing the body of the speech or oration (Tsikata, 2019). According to Foss (2008), it designates two ways of placing labels on the pentad, namely internal and external. The pentad used internally, and its elements focus on the content of the original rhetorical artifact, the content is examined from the orator's point of view or how the orator constructs the world. Then the pentad used externally relies on gathering contextual information or information outside of the rhetorical artifact itself. 
Meanwhile, the Propaganda Theory is explained by Lasswell (1927) as the management of collective attitudes or behaviors by manipulating symbols that are considered significant. The term collective behavior is described here as a form of effort in describing public opinion (Lasswell, 1927). Lasswell tries to capture the stimuli, which then produces a reaction which is formed with a "significant symbol."

However, the epistemological meaning of propaganda, is an uptake from modern Latin, namely propagate, which means to expand or develop (Bachtiar et al., 2016). Many academics, especially in a scientific view, assess propaganda as a series of messages that contextually aim to develop a public opinion and collective behavior of society with a number of symbolic stimuli significantly.

The purpose of propaganda activities can be carried out for various purposes. Lasswell (1927) explain at least four purposes of propaganda. First, as a means of cultivating hatred against the enemy. Second, to preserve friendship with allies, the third goal is to maintain friendship and the goal, if possible, is to establish cooperation with neutral parties. Fourth, to destroy the enemy's spirit.

If we observe more deeply, political propaganda has developed especially in psychological warfare (Bachtiar et al., 2016) for the sake of certain parties to get its essence. Herbert Blumer, who later developed this theory, stated that the propaganda goals from what Lasswell originally put forward had changed a lot to create impulses and beliefs for an action based on these beliefs (Bachtiar et al., 2016). So this explains how Propaganda Theory works using significant symbols.

As a means of spreading messages and symbolic meanings, there are at least seven propaganda tools (The Device of Propaganda) contained in the book The Fine Art of Propaganda. (Lee \& Lee, 1939). First, namely using the term or mention of ridicule, in which the naming of ridicule for an idea, rank, race, religious belief, national group, and others so that the 
wider public can insult and reject without the need to examine its truth. Second, using terms or words that are grandiose, namely using grandiose terms so that the public or the public can collectively agree on and accept this. Third, the use of power or prestige has an honorific value to be transferred to something so that the public can accept it. Fourth, doing quotations, namely by quoting words or sentences from many prominent figures to support the good or bad of an idea or product. Fifth, through propaganda techniques, self-humiliation can gain public sympathy and ensure that the character is decent and good. Sixth, falsifying, namely by covering the facts and truths through false evidence to deceive the public. Seventh, this technique is carried out by inviting the public collectively and in a crowd to accept and agree on an idea or program by provoking their belief that the other group or party has first agreed.

\section{METHODS}

This study uses an interpretive paradigm in hermeneutics' study by making symbols that appear in human conversations and actions as research objects. Then this research uses a qualitative approach to describe and explain the case study in-depth and explanation. Kenneth Burke's dramatic pentad method also provides a framework for interpretive research (Griffin, 2012). The analysis discussion was further elaborated using The Device of Propaganda (Lee \& Lee, 1939) to discover the political propaganda put forward by HRS in the speech at the 212 Grand Reunion.

The stages and processes of this research method include: 1) Documenting data in the form of HRS's speech at the 212 Grand Reunion held on December 2, 2019, by transcribing the verbatim contents of the speech, the video was uploaded to the YouTube channel SalingSapa TV; 2) Categorizing the HRS speech text by adjusting the concepts used in the study referring to Kenneth Burke's dramatic pentad; 3) Analyzing the HRS 
speech text to find motives and substance by interpreting the rhetoric carried out by HRS as a speaker in the dramatized pentad method and followed by The Device of Propaganda.

\section{RESULTS AND DISCUSSION}

Based on the transcripts of the contents of Habib Rizieq Shihab's speech, which was conveyed via video teleconference at the 212 Grand Reunion at Monas, Central Jakarta, which was held on Monday, December 2, 2019, could be dissected and mapped the elements contained therein. This research focuses on the text of HRS's speech, which conveyed five messages to the 212 Grand Reunion participants in a video uploaded through the YouTube channel SalingSapa TV. The contents of rhetoric or speech related to HRS's five mandates for the 212 Grand Reunion participants were revealed at 11:52 minutes to 30:15 minutes.

It is necessary to underline that the analysis carried out interprets the "drama" in the speech, not the speech itself (Griffin, 2012). The analysis will map the elements of act, agent, agency, scene, and purpose in the speech and interpret the symbolic actions in it (Griffin, 2012). The analysis continued with the implications that the HRS rhetoric had for the 212 Grand Reunion participants, which was based on the motives that appeared in the pentad analysis that had been carried out.

\section{Agent Element}

In the contents of his speech, HRS had repeatedly touched on the problem of "the struggle for justice" in the key points he conveyed. Although in the HRS context, the mandate is aimed explicitly at Indonesian Muslims and general for all Indonesians and people. Then HRS also touched on Ahok's return, and the group he claimed were Ahok's supporters during the election. HRS also mentioned other groups considered to be blasphemers of religion who are protected by law enforcers. 
Table 1.

HRS Rhetoric Text Snippet on Element Agent

\begin{tabular}{|c|c|c|}
\hline Agent element & $\begin{array}{c}\text { Rhetorical } \\
\text { Context }\end{array}$ & Breaking \\
\hline $\begin{array}{l}\text { "Kepada segenap peserta Reuni Akbar 212, } \\
\text { akhirnya melalui sambutan dalam Reuni Akbar } \\
212 \text { di tahun } 2019 \text { ini saya ingin menyampaikan } \\
\text { amanat perjuangan..." }\end{array}$ & God-term & \multirow{3}{*}{ 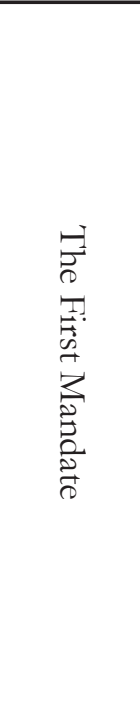 } \\
\hline $\begin{array}{l}\text { "...momentum yang luar biasa, momentum } \\
\text { persaudaraan, dan persatuan bagi umat Islam } \\
\text { di Indonesia, pada khususnya, bahkan bagi } \\
\text { seluruh rakyat dan bangsa Indonesia pada } \\
\text { umumnya." }\end{array}$ & God-term & \\
\hline $\begin{array}{l}\text { "...Reuni Akbar } 212 \text { setiap tahun dengan jutaan } \\
\text { peserta tapi tetap menampilkan ketertiban, } \\
\text { kesejukan, kedamaian, ketenangan, keselamatan, } \\
\text { persahabatan, pergaulan, kekeluargaan aneka } \\
\text { ragam keindahan..." }\end{array}$ & God-term & \\
\hline $\begin{array}{l}\text { "Oleh karenanya saya sudah berulang kali dan } \\
\text { sudah sering sekali saya sampaikan kepada } \\
\text { seluruh umat Islam Indonesia, bahkan seluruh } \\
\text { rakyat dan bangsa Indonesia jika } 1000 \text { kali kita } \\
\text { jatuh dan gagal dalam perjuangan penegakkan } \\
\text { keadilan, maka } 1001 \text { kali kita harus siap bangun } \\
\text { dan bangkit kembali (panitia: Allahuakbar! } \\
\text { (diikuti seluruh peserta))..." }\end{array}$ & God-term & 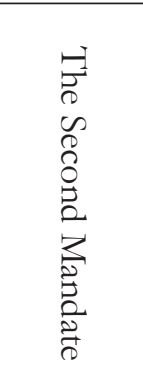 \\
\hline $\begin{array}{l}\text { "Jangan sampai satu-dua kegagalan yang } \\
\text { kita alami di dalam suatu rangka perjuangan } \\
\text { memupuskan harapan kita untuk meraih } \\
\text { kemenangan." }\end{array}$ & God-term & 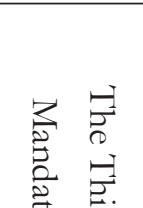 \\
\hline $\begin{array}{l}\text { "...ingat juga akan janji Allah SWT bahwasanya } \\
\text { siapa yang berjuang untuk Allah pasti menang..." }\end{array}$ & God-term & \\
\hline
\end{tabular}




\begin{tabular}{|c|c|c|}
\hline Agent element & $\begin{array}{c}\text { Rhetorical } \\
\text { Context }\end{array}$ & Breaking \\
\hline $\begin{array}{l}\text { "...An-Nabi SAW pernah menyatakan dan } \\
\text { mengamanatkan kepada kita semua, 'alaikum } \\
\text { bil jamaah, wa iyyakum minal furqah, wajib atas } \\
\text { kamu kalau berjuang itu, beramal itu, beribadah } \\
\text { itu dengan berjamaah, bersatu bergotong- } \\
\text { royong di dalam kita melakukan perjuangan." }\end{array}$ & God-term & \\
\hline $\begin{array}{l}\text { "Karena itu kita ingatkan pada semua bahwa } \\
\text { kita semua membutuhkan pertolongan Allah } \\
\text { SWT, kalau sudah ada pertolongan Allah } \\
\text { SWT tidak ada satupun kekuatan yang dapat } \\
\text { mengalahkan kita semua. Ingat sekuat apapun } \\
\text { kekuasaan kita, sebanyak apapun jumlah kita, } \\
\text { sebesar apapun tenaga kita, sekaya apapun } \\
\text { harta benda kita dan sehebat apapun strategi } \\
\text { kita tanpa pertolongan Allah semua itu tidak } \\
\text { akan ada artinya dan sebaliknya, sebaliknya, } \\
\text { selemah apapun kekuasaan kita, sedikit apapun } \\
\text { jumlah kita, sekecil apapun tenaga kita, semiskin } \\
\text { apapun harta benda kita dan sepayah apapun } \\
\text { strategi kita manakala pertolongan Allah SWT } \\
\text { sudah datang kepada kita, maka semuanya akan } \\
\text { berubah menjadi satu kekuatan yang dahsyat } \\
\text { dan tidak ada satu kekuatan dari manapun, dari } \\
\text { siapapun yang akan mampu mengalahkan kita." }\end{array}$ & God-term & 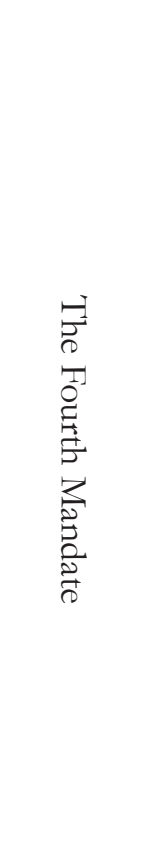 \\
\hline $\begin{array}{l}\text { "...wajib kita selalu bertakwa kepada Allah } \\
\text { dengan menjalankan segala perintahnya, } \\
\text { meninggalkan segala larangannya." }\end{array}$ & God-term & \\
\hline $\begin{array}{l}\text { "...saya ingatkan kepada seluruh peserta Reuni } \\
\text { Akbar } 212 \text { ini teruslah berjuang dengan } \\
\text { keikhlasan, kesabaran, dan kebersamaan." }\end{array}$ & God-term & \\
\hline
\end{tabular}




\begin{tabular}{|c|c|c|}
\hline Agent element & $\begin{array}{l}\text { Rhetorical } \\
\text { Context }\end{array}$ & Breaking \\
\hline $\begin{array}{l}\text { "Terus kita berjuang dalam membela agama, } \\
\text { bangsa, dan negara." }\end{array}$ & God-term & \\
\hline $\begin{array}{l}\text { "...saya ingin serukan kepada segenap umat } \\
\text { Islam di seluruh Indonesia, begitu juga seluruh } \\
\text { rakyat dan bangsa Indonesia jika terjadi suatu } \\
\text { penodaan agama, jika ada yang menghina Allah } \\
\text { SWT atau Rasulullah SAW atau melecehkan } \\
\text { Alquranulkarim atau menodai agama Islam, } \\
\text { maka kita serukan kepada seluruh umat Islam } \\
\text { untuk memproses secara hukum." }\end{array}$ & God-term & 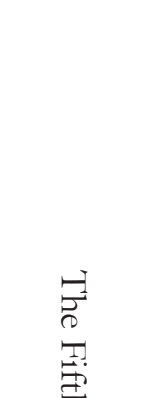 \\
\hline $\begin{array}{l}\text { "...saya serukan ke seluruh umat Islam di } \\
\text { tanah air, bahkan seluruh rakyat dan bangsa } \\
\text { Indonesia, untuk menggelar Aksi Bela Agama } \\
\text { yang berjilid-jilid! Kepada umat Islam gelar } \\
\text { Aksi Bela Islam yang berjilid-jilid! Sebagaimana } \\
\text { pernah kita (panitia: Allahuakbar! (diikuti } \\
\text { seluruh peserta)) lakukan bersama-sama..." }\end{array}$ & God-term & 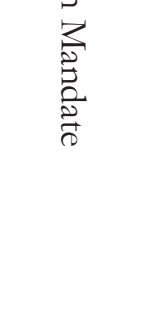 \\
\hline $\begin{array}{l}\text { "...kepada seluruh umat Islam, tolong buat gelar } \\
\text { aksi yang berjilid-jilid! Jangan pernah berhenti } \\
\text { itu aksi..." }\end{array}$ & God-term & \\
\hline
\end{tabular}

When referring to the context of an ongoing activity, the agents in question are people who are committed to action (Griffin, 2012). So the agent in the HRS speech was addressed to the participants of Reunion Akbar 212 and PA 212. This refers to how HRS mentioned explicitly in its first mandate by saying the giving of this mandate to the participants of Reunion Akbar 212, which means more relevant when the agent's referral from the content of HRS speech is the participants of Reunion Akbar 212. Participants of Reunion Akbar 212, including FPI, HTI, GNPFMUI, FUI, and PA 212, were mentioned by HRS at the opening speech.

HRS construction rhetorical construction uses god-terms or sentences that describe everything that the orator or speaker values and 
considers to be something true and good (Griffin, 2019). The agent's action commitment is considered in accordance with the construction of the rhetoric delivered by the speaker. The agent is a person who can place ideas, desires, fears, envy, intuition, imagination, and personal expression (Suparno, 2011). This can be attributed to HRS's statement stating that Reunion Akbar 212 should display order, coolness, peace, tranquility, security, friendship, association, and family that can be created by the participants reunion itself.

However, the rhetorical construction of HRS can also be identified by two other groups of agents who become scapegoats, i.e., a person or group accused of a mistake by a speaker or orator (Griffin, 2019). Identifying these two groups of agents appears to demonstrate the affirmation of the first group of agents' commitment to action adequately constructed and well. The form of scapegoating performed by HRS on these two groups of agents uses the devil-term to describe things that are considered bad, wrong, and evil by the speaker or orator (Griffin, 2019). However, there are god-term forms used repeatedly in the context of scapegoating.

Table 2.

HRS Rhetoric Text Snippet On Element Agent

\begin{tabular}{lll}
\hline Agent element & $\begin{array}{c}\text { Rhetorical } \\
\text { Context }\end{array}$ & Breaking \\
\hline "...Ahok si penista agama lengser dan longsor!" & $\begin{array}{c}\text { Scapegoating; } \\
\text { Devil-term }\end{array}$ \\
\hline "...kita sama tahu Ahok si penista agama saatitu & \\
dinaungi presiden, dijaga Kapolri, dilindungi & \\
panglima TNI, dibela KPU dan KPK, diusung \\
partai-partai besar, dikampanyekan semua \\
media nasional, bersama para pengamat dan \\
berbagai lembaga polling, didanai konglomerat \\
$\begin{array}{l}\text { Sembilan Naga Merah, bahkan ASN -pegawai } \\
\text { negeri diwajibkan untuk memilihnya." }\end{array}$
\end{tabular}




\begin{tabular}{|c|c|c|}
\hline Agent element & $\begin{array}{c}\text { Rhetorical } \\
\text { Context }\end{array}$ & Breaking \\
\hline $\begin{array}{l}\text { "...PBNU ikut berusaha memenangkannya } \\
\text { dan tidak kurang preman dan dukun pun } \\
\text { dikerahkan serta Ahok mendapatkan } \\
\text { dukungan dari dalam dan luar negeri." }\end{array}$ & $\begin{array}{l}\text { Scapegoating; } \\
\text { Devil-term }\end{array}$ & \\
\hline $\begin{array}{l}\text { "...si Ahok penista agama yang di-backup } \\
\text { (panitia: semua tetap duduk, semua tetap } \\
\text { duduk) oleh kekuatan yang dimiliki oleh rezim } \\
\text { zalim ini saudara." }\end{array}$ & $\begin{array}{l}\text { Scapegoating; } \\
\text { Devil-term }\end{array}$ & \\
\hline $\begin{array}{l}\text { "...ada orang yang membandingkan Rasulullah } \\
\text { SAW dengan ayatnya, dia merasa ayatnya } \\
\text { lebih baik dari Rasulullah SAW. Ada lagi } \\
\text { menggambarkan kehidupan masa kecil Nabi } \\
\text { "Alaihisshalatuwassalam dengan masa kecil } \\
\text { yang dekil, kumel, kotor, tidak terurus. Ada } \\
\text { ada juga orang yang secara terang-terangan } \\
\text { menyebut bahwa terorisme itu punya agama } \\
\text { dan agama terorisme itu adalah Islam." }\end{array}$ & God-term & 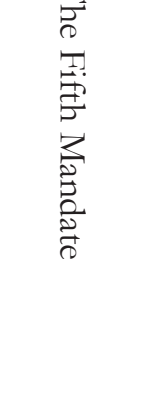 \\
\hline
\end{tabular}

HRS combines devil-term and god-term in one construction in two groups of agents, even in groups of law enforcement agents and blasphemers are called repeatedly with the same action context. So this can be related to the tendency of HRS's statement, which assesses law enforcers through the verbal symbol "Kapolri," is on the opposition side of the first agent group, namely PA 212. It also shows HRS sending messages or discourse to law enforcers through god-term rhetoric that contains threats. Several times, when HRS constructed this scapegoating in the fifth mandate, the committee in the Monas area shouted the Takbir sentence, which was followed by the Akbar Reunion participants, this symbolic act associating the commitment of the first agent group with HRS's scapegoating. 
Table 3.

HRS Rhetoric Text Snippet on Element Agent

\begin{tabular}{|c|c|c|}
\hline Agent element & $\begin{array}{c}\text { Rhetorical } \\
\text { Context }\end{array}$ & Breaking \\
\hline $\begin{array}{l}\text { "Jika penegak hukum tidak mau } \\
\text { menegakkan hukum sebagaimana mestinya } \\
\text { bahkan para penegak hukum membiarkan } \\
\text { penodaan agama itu terjadi, bahkan justru } \\
\text { penegak hukum itu yang melindungi para } \\
\text { penoda agama." }\end{array}$ & $\begin{array}{l}\text { Scapegoating; } \\
\text { Devil-term }\end{array}$ & \multirow{6}{*}{ 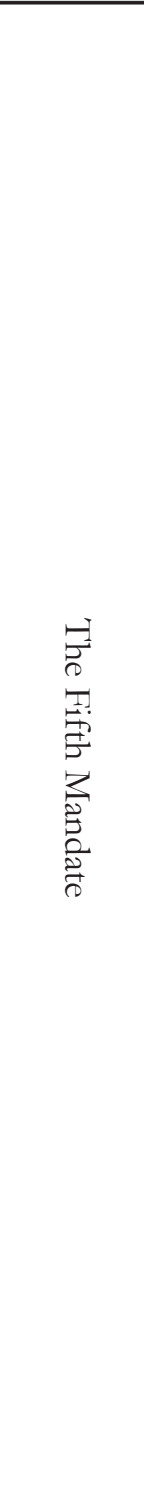 } \\
\hline $\begin{array}{l}\text { "...kalau aksi bela Islam sudah digelar } \\
\text { berjilid-jilid tapi penegak hukum tetap saja } \\
\text { membiarkan si penoda agama, bahkan } \\
\text { melindungi para penoda agama tersebut } \\
\text { saudara..." }\end{array}$ & $\begin{array}{l}\text { Scapegoating; } \\
\text { Devil-term }\end{array}$ & \\
\hline $\begin{array}{l}\text { "Kalau aparat penagak hukum tidak ingin } \\
\text { menegakkan undang-undang..." }\end{array}$ & $\begin{array}{l}\text { Scapegoating; } \\
\text { Devil-term }\end{array}$ & \\
\hline $\begin{array}{l}\text { "...jika aksi bela agama yang berjilid-jilid } \\
\text { di berbagai daerah, tetep tidak mendapat } \\
\text { perhatian bahkan para penegak hukum } \\
\text { tetep membiarkan penodaan agama bahkan } \\
\text { justru melindungi para penoda agama..." }\end{array}$ & $\begin{array}{l}\text { Scapegoating; } \\
\text { Devil-term }\end{array}$ & \\
\hline $\begin{array}{l}\text { "...maka jangan salahkan umat Islam! Jika } \\
\text { umat Islam mengambil tindakan sendiri, } \\
\text { sesuai keyakinannya yang sudah ditetapkan } \\
\text { oleh ajaran syariat Islam yaitu hukuman } \\
\text { mati! Secara cerdas." }\end{array}$ & God-term & \\
\hline $\begin{array}{l}\text { "...maka sekali lagi jangan salahkan umat } \\
\text { Islam jika mereka mengambil tindakan } \\
\text { sendiri, sesuai keyakinan mereka, di dalam } \\
\text { ajaran syariat Islam bahwa penoda agama, } \\
\text { penghina Allah, penghina nabi, penista } \\
\text { Al quran adalah hukuman mati! (panitia: } \\
\text { Allahuakbar! (diikuti seluruh peserta)) } \\
\text { Secara cerdas." }\end{array}$ & God-term & \\
\hline
\end{tabular}




\section{Elemen Act}

This element in the HRS speech content symbolically needs to be translated one by one so that it is able to form a network that is connected to one another. Because this element refers more to the big context of the actions taken by the agent (Tsikata, 2019).

Table 4.

HRS Rhetoric Text Snippet on Element Act

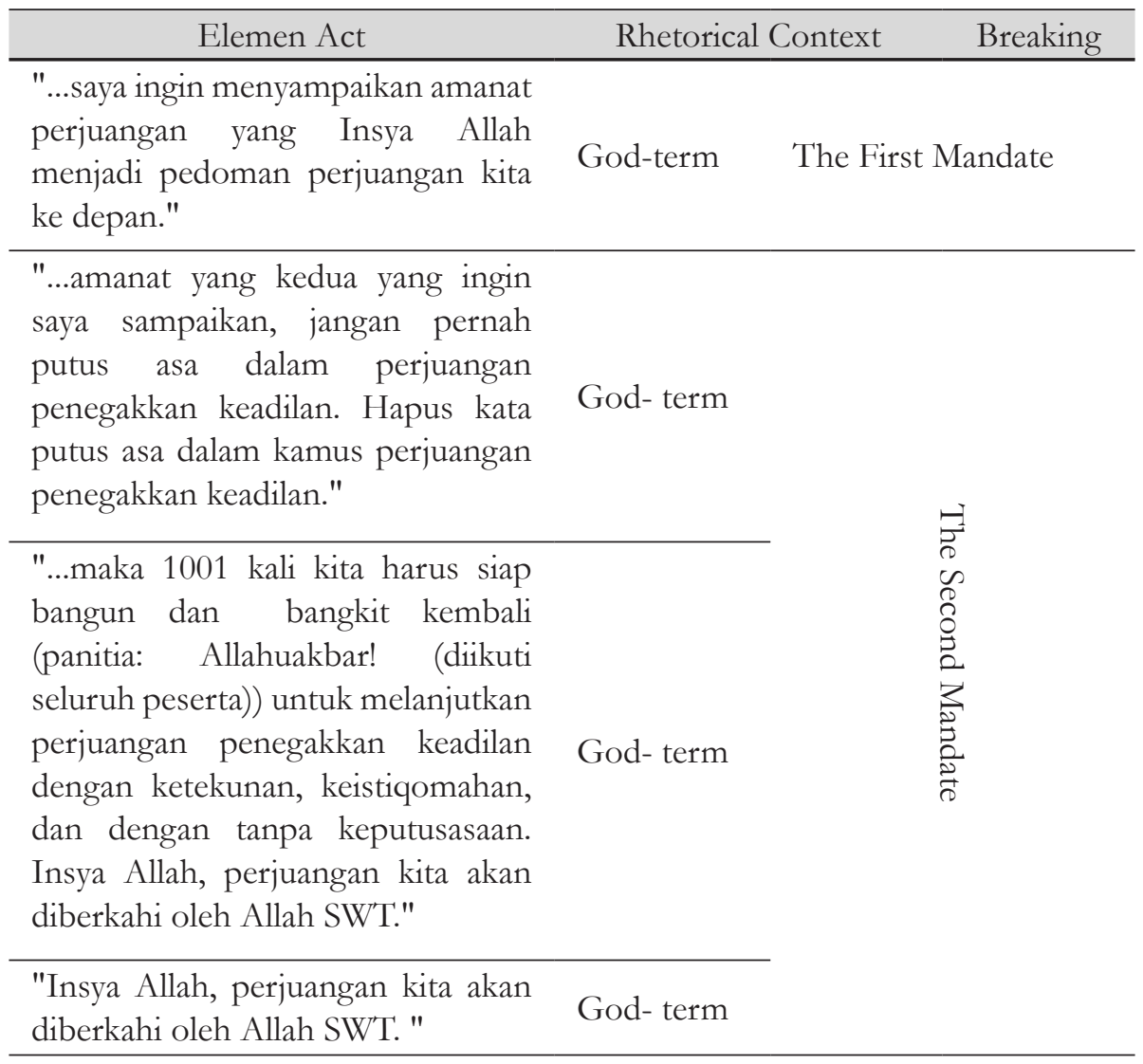




\begin{tabular}{|c|c|c|}
\hline Elemen Act & Rhetorical Context & Breaking \\
\hline $\begin{array}{l}\text { "Jangan sampai satu-dua kegagalan } \\
\text { yang kita alami di dalam perjuangan } \\
\text { penegakkan keadilan memudarkan } \\
\text { keyakinan kita akan janji Allah } \\
\text { SWT. Ingat, bahwa Allah SWT } \\
\text { menegaskan kepada kita bahwa } \\
\text { jalan-jalan kemenangan untuk } \\
\text { meraih ridha Allah SWT sangat } \\
\text { banyak, sangat banyak, sehingga } \\
\text { tidak ada alasan bagi kita untuk } \\
\text { berputus asa. Allah firmankan } \\
\text { dalam Surat Al-Ankabut ayat 69..." }\end{array}$ & God- term & 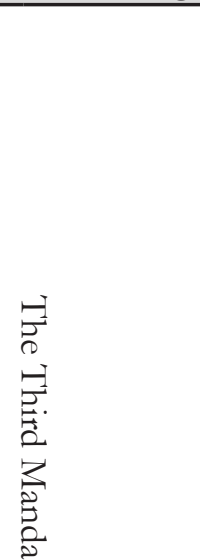 \\
\hline $\begin{array}{l}\text { "Selain itu, ingat juga akan janji } \\
\text { Allah SWT bahwasanya siapa yang } \\
\text { berjuang untuk Allah pasti menang, } \\
\text { sebagaimana Allah SWT berfirman } \\
\text { dalam Surat Muhammad ayat ke- } \\
\text { 7..." }\end{array}$ & God- term & \\
\hline
\end{tabular}

"Amanat yang keempat yang tidak kalah pentingnya dengan amanatamanat sebelumnya teruslah berjuang dengan keikhlasan dan kebersamaan. Karena pertolongan Allah SWT ada pada keikhlasan dan kebersamaan."

"Jawabnya karena ketika itu Islam berjuang dengan ikhlas dengan sabar dan bersatu berjuang bersama melawan kedzaliman untuk menegakkan keadilan. Karenanya sekali lagi saya ingatkan God- term kepada seluruh peserta Reuni Akbar 212 ini teruslah berjuang dengan keikhlasan, kesabaran, dan kebersamaan. " 


\begin{tabular}{|c|c|c|}
\hline Elemen Act & Rhetorical Context & Breaking \\
\hline $\begin{array}{l}\text { "Turun ke jalan aksi! Jangan pernah } \\
\text { takut! Jangan pernah berhenti! } \\
\text { Dalam membela agama, bangsa, } \\
\text { dan negara." }\end{array}$ & God- term & \multirow{2}{*}{ 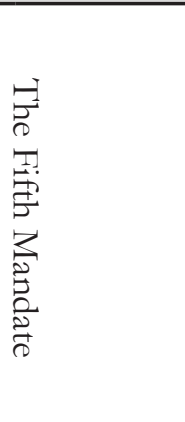 } \\
\hline $\begin{array}{l}\text { "Itulah yang bisa sampaikan dalam } \\
\text { amanat yang kelima ini semoga kita } \\
\text { semua tetap tidak pernah berhenti } \\
\text { membela agama, bangsa, dan } \\
\text { negara." }\end{array}$ & God- term & \\
\hline
\end{tabular}

HRS's first mandate mentioned that its mandate guides the struggle to be used in the future. The same thing in the second mandate, namely regarding the "struggle for justice" without feeling hopeless. The three mandate HRS is used to raise the belief in Allah's promise even though it fails in a struggle. HRS uses Surat Al-Ankabut verse 69 and Surat Muhammad verse 7, which talk about the struggle and upholding justice.

Almost the same thing also appeared in the fourth and fifth messages delivered by HRS. HRS briefly touched on the history of the PA 212 group, which carried out actions to defend Islam in volumes from 2016 to 2017. HRS also called for never ceasing to defend religion, nation, and state. As well as the urgency to take to the streets. So, as a result of elaborating a series of points that could be highlighted earlier, the context that can be linked to the existence of an element of action is "the struggle for justice." This action results from the formation of motives that tend to be repeated and emphasized to form motivation in drama (Suparno, 2011), which is then associated with the agent. The symbolic redundancy of the "struggle for justice" will explain HRS's rhetoric's agency element.

\section{Elemen Scene}

The speech delivered by HRS resulted from a video recording of a teleconference located in Mecca, Saudi Arabia. However, if you look 
at the video's location, it takes place in the Monas area, Central Jakarta. So that in this scene element, it is necessary to look more contextually from the HRS speech to find symbolic descriptions of the scene. This element is formed in an environment of agency, action, and agency occurs (Griffin, 2012). So the symbolic form of the HRS speech context can be the conditions and situations discussed in the speech. Furthermore, Tsikata (2019) mentions, scene elements are the source or impetus of action. So this analysis tries to interpret the rhetorical constructs formed by HRS in shaping the environmental context.

Table 5.

HRS Rhetoric Text Snippet on Scene Element

\begin{tabular}{|c|c|c|}
\hline Breaking & Elements of Scene & Rhetorical Context \\
\hline \multirow[b]{2}{*}{ 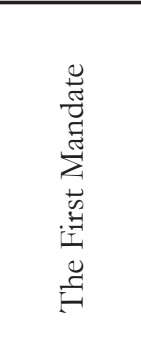 } & $\begin{array}{l}\text { "...amanat pertama, jagalah tradisi Reuni Akbar } 212 \\
\text { dengan segala keindahannya..." }\end{array}$ & God-term \\
\hline & $\begin{array}{l}\text { "Sehingga sekali lagi kita perlu tradisikan } \\
\text { Reuni Akbar } 212 \text { dengan segala keindahannya, } \\
\text { kedamaiannya, kesejukannya, ketertibannya } \\
\text { kedisiplinannya begitu juga dengan kebersihannya } \\
\text { tunjukkanlah kepada dunia inilah negara Republik } \\
\text { Indonesia..." }\end{array}$ & God-term \\
\hline \multirow{2}{*}{ 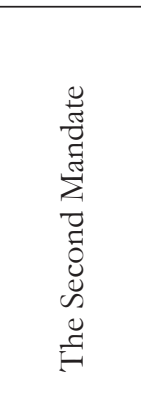 } & $\begin{array}{l}\text { "...jangan pernah putus asa dalam perjuangan } \\
\text { penegakkan keadilan. Hapus kata putus asa dalam } \\
\text { kamus perjuangan penegakkan keadilan..." }\end{array}$ & God-term \\
\hline & $\begin{array}{l}\text { “...sudah sering sekali saya sampaikan kepada } \\
\text { seluruh umat Islam Indonesia, bahkan seluruh } \\
\text { rakyat dan bangsa Indonesia jika } 1000 \text { kali kita jatuh } \\
\text { dan gagal dalam perjuangan penegakkan keadilan, } \\
\text { maka } 1001 \text { kali kita harus siap bangun dan bangkit } \\
\text { kembali }\end{array}$ & God-term \\
\hline
\end{tabular}




\begin{tabular}{|c|c|c|}
\hline Breaking & Elements of Scene & Rhetorical Context \\
\hline \multirow{3}{*}{ 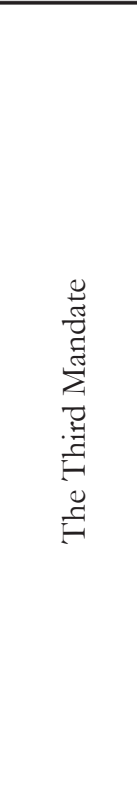 } & $\begin{array}{l}\text { "...saya sampaikan dari Kota Suci Mekkah Al } \\
\text { Mukarromah dalam Reuni Akbar } 212 \text { ini adalah } \\
\text { percayalah dan yakinlah dengan janji Allah SWT. } \\
\text { Jangan sampai satu-dua kegagalan yang kita alami } \\
\text { di dalam suatu rangka perjuangan memupuskan } \\
\text { harapan kita untuk meraih kemenangan." }\end{array}$ & God-term \\
\hline & $\begin{array}{l}\text { "Allah sudah menyampaikan kepada kita bahwa } \\
\text { jalan kemenangan untuk menuju ridha Allah begitu } \\
\text { banyak, satu jalan tertutup masih ada jalan-jalan lain } \\
\text { yang terbuka. Jadi percayalah dengan janji Allah, } \\
\text { yakinlah dengan janji Allah, janji Allah SWT akan } \\
\text { terwujud dalam kehidupan kita..." }\end{array}$ & God-term \\
\hline & $\begin{array}{l}\text { "Sekali lagi percayalah dengan janji Allah, yakinlah } \\
\text { dengan janji Allah, nasrunminallah wakhuqulkarib } \\
\text { wabasyir mu'miniin, pertolongan datangnya dari } \\
\text { Allah dan kemenangan sudah dekat, dan berikanlah } \\
\text { kabar gembira kepada orang-orang yang beriman." }\end{array}$ & God-term \\
\hline \multirow{4}{*}{ 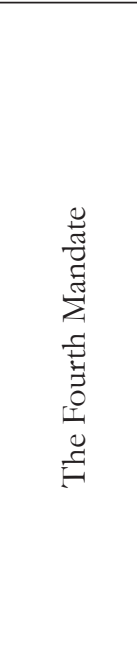 } & $\begin{array}{l}\text { "....wajib atas kamu kalau berjuang itu, beramal itu, } \\
\text { beribadah itu dengan berjamaah, bersatu bergotong- } \\
\text { royong di dalam kita melakukan perjuangan." }\end{array}$ & God-term \\
\hline & $\begin{array}{l}\text { "Kenapa? Jamaah, kata nabi, karena sesungguhnya } \\
\text { tangan Allah, pertolongan Allah, ridha Allah, } \\
\text { rahmat Allah ada pada kebersamaan." }\end{array}$ & God-term \\
\hline & $\begin{array}{l}\text { "... karena adanya pertolongan Allah SWT lantaran } \\
\text { keikhlasan dan kebersamaan umat Islam Indonesia } \\
\text { dalam melawan arogansi rezim zalim. Belajar dari } \\
\text { sana disana ada pertolongan Allah SWT..." }\end{array}$ & God-term \\
\hline & $\begin{array}{l}\text { ".... semua kekuatan pendukung si penista agama } \\
\text { rontok, rontok! Inilah pertolongan Allah SWT yang } \\
\text { diberikan Allah SWT kepada umat Islam kenapa } \\
\text { Allah SWT memenangkan umat Islam ketika itu?" }\end{array}$ & God-term \\
\hline
\end{tabular}




\begin{tabular}{|c|c|c|}
\hline Breaking & Elements of Scene & Rhetorical Context \\
\hline \multirow{5}{*}{ 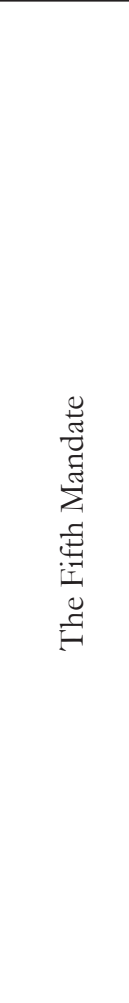 } & $\begin{array}{l}\text { "Sebagaimana sama kita ketahui bahwa saat ini di } \\
\text { kita punya negeri telah terjadi aneka ragam peristiwa } \\
\text { penodaan agama..." }\end{array}$ & God-term \\
\hline & $\begin{array}{l}\text { "...negara Indonesia adalah negara hukum dan kita } \\
\text { punya undang-undang anti penodaan agama sesuai } \\
\text { dengan Perpres No. } 1 \text { tahun } 1965 \text { juga ada KUHP } \\
\text { pasal 156A proses secara hukum sesuai dengan } \\
\text { undang-undang yang berlaku di Negara Kesatuan } \\
\text { Republik Indonesia." }\end{array}$ & God-term \\
\hline & $\begin{array}{l}\text { "Sekali lagi, sekali lagi, saya ingin tekankan di sini } \\
\text { jika terjadi penodaan agama, maka proses hukum } \\
\text { sesuai undang-undang yang berlaku di negara kita." }\end{array}$ & God-term \\
\hline & $\begin{array}{l}\text { "...gelar aksi bela agama berjilid-jilid di semua } \\
\text { daerah, gelar dan gelar kembali di ibukota di Jakarta } \\
\text { secara besar-besaran! Gelar! Tekan terus!" }\end{array}$ & God-term \\
\hline & $\begin{array}{l}\text { "..catat baik-baik, agama apapun tidak boleh } \\
\text { dinodai, agama apapun tidak boleh dihina, agama } \\
\text { apapun tidak boleh dilecehkan. Apalagi agama } \\
\text { Islam yang menjadi agama mayoritas daripada } \\
\text { rakyat dan bangsa Indonesia!” }\end{array}$ & God-term \\
\hline
\end{tabular}

The first mandate of HRS raises the context of unity and tradition of the 212 Grand Reunion, then in the second mandate refers to the failure that has been experienced and is being fought back by PA 212 . The third mandate has a spiritual and religious context, which is used by HRS as a motive to strengthen the other four mandates. The fourth mandate brings the historical and social context of PA 212. Meanwhile, the fifth mandate is more about the mission that needs to be carried out. So contextually, this scene's elements reinforce the PA 212 movement and other organizations that accompany it. So there is a form of mediated communication through HRS to the grand reunion participants so that there is a strengthening of the agents' action commitment. 


\section{Agency Element}

Griffin explains if the agency is how the procedure of action is carried out by the agent (Griffin, 2012). It can explain how agencies in the HRS mandate become a procedure that is also a function of the goals to be achieved by the agent.

Table 6.

HRS Rhetoric Text Snippets on Element Agency

\begin{tabular}{|c|c|c|}
\hline Breaking & Agency Elemen & Rhetorical Context \\
\hline 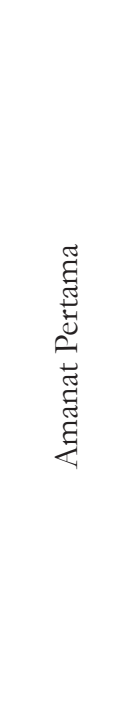 & $\begin{array}{l}\text { “...jagalah tradisi Reuni Akbar } 212 \text { dengan segala } \\
\text { keindahannya sebab Reuni Akbar } 212 \text { merupakan } \\
\text { momentum yang teramat penting, momentum } \\
\text { yang luar biasa, momentum persaudaraan, dan } \\
\text { persatuan bagi umat Islam di Indonesia, pada } \\
\text { khususnya, bahkan bagi seluruh rakyat dan bangsa } \\
\text { Indonesia pada umumnya. Sehingga sekali lagi kita } \\
\text { perlu tradisikan Reuni Akbar } 212 \text { dengan segala } \\
\text { keindahannya, kedamaiannya, kesejukannya, } \\
\text { ketertibannya kedisiplinannya begitu juga dengan } \\
\text { kebersihannya tunjukkanlah kepada dunia inilah } \\
\text { negara Republik Indonesia yang mampumenggelar } \\
\text { acara Reuni Akbar } 212 \text { setiap tahun dengan } \\
\text { jutaan peserta tapi tetap menampilkan ketertiban, } \\
\text { kesejukan, kedamaian, ketenangan, keselamatan, } \\
\text { persahabatan, pergaulan, kekeluargaan aneka } \\
\text { ragam keindahan...” }\end{array}$ & God-term \\
\hline 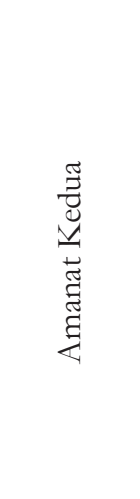 & $\begin{array}{l}\text { "Hapus kata putus asa dalam kamus perjuangan } \\
\text { penegakkan keadilan. Oleh karenanya saya } \\
\text { sudah berulang kali dan sudah sering sekali saya } \\
\text { sampaikan kepada seluruh umat Islam Indonesia, } \\
\text { bahkan seluruh rakyat dan bangsa Indonesia jika } \\
1000 \text { kali kita jatuh dan gagal dalam perjuangan } \\
\text { penegakkan keadilan, maka } 1001 \text { kali kita harus } \\
\text { siap bangun dan bangkit kembali (panitia: } \\
\text { Allahuakbar! (diikuti seluruh peserta)) untuk } \\
\text { melanjutkan perjuangan penegakkan keadilan } \\
\text { dengan ketekunan, keistiqomahan, dan dengan } \\
\text { tanpa keputusasaan." }\end{array}$ & God-term \\
\hline
\end{tabular}




\begin{tabular}{clc}
\hline Breaking & \multicolumn{1}{c}{ Agency Elemen } & Rhetorical Context \\
\hline & “...teruslah berjuang dengan keikhlasan dan & \\
kebersamaan. Karena pertolongan Allah SWT ada & \\
pada keikhlasan dan kebersamaan...” & God-term \\
& & \\
& & \\
agama, maka proses hukum sesuai undang-undang & \\
yang berlaku di negara kita. Kalau aparat penagak & \\
hukum tidak ingin menegakkan undang-undang & \\
tersebut maka gelar aksi bela agama berjilid- & God-term; \\
jilid di semua daerah, gelar dan gelar kembali di & \\
ibukota di Jakarta secara besar-besaran! Gelar! & \\
Tekan terus! Sampai si penoda agama itu diproses & \\
hukum, diseret ke meja hijau, dan dijebloskan ke & \\
penjara dengan hukuman penjara yang setimpal.” & \\
\hline
\end{tabular}

Seeing the contents of the HRS speech, referring to several parts. In the first mandate, HRS's procedure wants to construct to the agent through its rhetoric about maintaining the 212 Grand Reunion tradition with all the positive contexts it carries. The second mandate of the construction of agency elements is shown by the motive of eliminating the word despair in the struggle carried out in the agent's spiritual strengthening procedure on the previous act element. The fourth mandate binds the agency elements of other mandates, emphasizing civility and togetherness that PA 212 needs to rebuild. Then the fifth mandate refers to procedures that are directly related to the elements of act and agent, namely the emphasis on law enforcement in the interests of PA 212 in especially although HRS tends to mention it in the interests of Indonesian Muslims.

Seeing the contents of the HRS speech, referring to several parts. In the first mandate, HRS's procedure wants to construct to the agent through its rhetoric is about maintaining the tradition of the 212 Grand Reunion with all the positive contexts it carries. The second mandate of 
the construction of agency elements is shown by the motive of eliminating the word despair in the struggle carried out in the agent's spiritual strengthening procedure on the previous act element. The fourth mandate binds the agency elements of other mandates with an emphasis on civility and togetherness that PA 212 needs to rebuild. Then the fifth mandate which refers to procedures that are directly related to the elements of act and agent, namely the emphasis on law enforcement in the interests of PA 212 in especially although HRS tends to mention it in the interests of Indonesian Muslims. The background to the action described in the previous act element can be associated with another element's symbol. The agent element aimed at the participants of the 212 Grand Reunion or PA 212 is an essential element related to the elements of the scene, namely the context of PA 212 to be strengthened again. The agency element clearly describes the procedures that are related to one another in the HRS mandate so that it shows the function of the objectives to be achieved.

Tabel 7.

HRS Rhetoric Text Snippet on Element Purpose

\begin{tabular}{|c|c|c|}
\hline Breaking & Purpose Element & Rhetorical Context \\
\hline 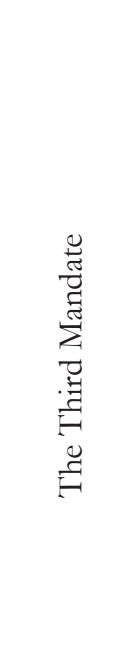 & $\begin{array}{l}\text { “...amanat yang ketiga yang ingin saya sampaikan } \\
\text { dari Kota Suci Mekkah Al Mukarromah dalam } \\
\text { Reuni Akbar } 212 \text { ini adalah percayalah dan yakinlah } \\
\text { dengan janji Allah SWT. Jangan sampai satu-dua } \\
\text { kegagalan yang kita alami di dalam suatu rangka } \\
\text { perjuangan memupuskan harapan kita untuk meraih } \\
\text { kemenangan. Jangan sampai satu-dua kegagalan yang } \\
\text { kita alami di dalam perjuangan penegakkan keadilan } \\
\text { memudarkan keyakinan kita akan janji Allah SWT. } \\
\text { Ingat, bahwa Allah SWT menegaskan kepada kita } \\
\text { bahwa jalan-jalan kemenangan untuk meraih ridha } \\
\text { Allah SWT sangat banyak, sangat banyak, sehingga } \\
\text { tidak ada alasan bagi kita untuk berputus asa. Allah } \\
\text { firmankan dalam Surat Al-Ankabut ayat 69, Allah } \\
\text { nyatakan, waalladhiinajahaduu fiinalanahdiyannahum } \\
\text { subulan }\end{array}$ & God-term \\
\hline
\end{tabular}




\begin{tabular}{|c|c|c|}
\hline Breaking & Purpose Element & Rhetorical Context \\
\hline 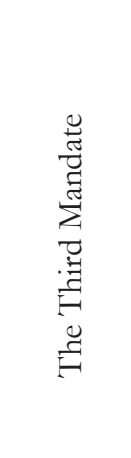 & $\begin{array}{l}\text { "Orang-orang berjihad di jalan Kami untuk meraih } \\
\text { ridha Kami, niscaya akan Kami tunjukkan kepada } \\
\text { mereka jalan-jalan Kami." Jadi dalam ayat ini Allah } \\
\text { sudah menyampaikan kepada kita bahwa jalan } \\
\text { kemenangan untuk menuju ridha Allah begitu banyak, } \\
\text { satu jalan tertutup masih ada jalan-jalan lain yang } \\
\text { terbuka. Jadi percayalah dengan janji Allah, yakinlah } \\
\text { dengan janji Allah, janji Allah SWT akan terwujud } \\
\text { dalam kehidupan kita ingat Innallah Yu'lifuul Mi'aad, } \\
\text { Sesungguhnya Allah tidak pernah dan tidak akan } \\
\text { pernah mengingkari janjinya." }\end{array}$ & God-term \\
\hline
\end{tabular}

So the purpose of HRS's mandate is strengthening the 212 Grand Reunion participants on God's promise, which can then explain as the background for the action's struggle for justice and scenes from the context of strengthening PA 212 through agencies or procedures carried out by agent.

\section{Discussion Of Propaganda Theory Perspectives}

When viewed from the HRS speech using a classic analytical framework from the seven propaganda tools, HRS several times used several derisive calls to the 212 Alumni group. As in the fourth mandate delivered by HRS, who repeatedly said, "Ahok the Blasphemer" and on the mandate The fifth also mentions the derogatory name "The Blasphemer of Religion" where this mention is designed to give nicknames for "enemies" and groups both near and far from Alumni 212 (Marshall, 2017). These groups are further mentioned in the HRS rhetoric, including the president, the police chief, the TNI commander, the KPU and KPK, major political parties, national media, survey poll observers and institutions, conglomerates, ASN, and PBNU.

The pentadic rhetoric analysis explains the mention of Ahok the Blasphemer of Religion and those who are considered to be his supporters 
as a form of scapegoating using devil-term. So this is related to how in the Propaganda Theory, the name mockery or name-calling serves to invite and associate agents (212 Alumni members) to commit to HRS's vision in building its rhetoric in viewing groups that are considered enemies or parties, which goes against their goal.

The use of name mocking or name-calling is also found in other designations such as "wrongdoing regime," which is used in the fourth and fifth mandates. This also refers to the assumption that Jokowi tends to take Ahok's side, such as the rumors that surfaced in the 2019 presidential election that said Jokowi might reconsider Ahok as his political partner (Marshall, 2017). Based on the propaganda perspective, name-calling by HRS is indeed used to label groups or positions so that the audience or Alumni 212 are committed to the group's rejection.

The second propaganda tool used in the construction of rhetoric by HRS was the glittering generalities widely used in the opening or preamble of the 212 Grand Reunion speech. Like the first message that emphasized the 212 Grand Reunion, this is a significant momentum that needs to be rendered with beauty, peace, tranquility, safety, and others. Ahyar (2019) explained that the Islamic mass action movement, also known as the Islamic Defense Action, is a form of victory for Islamic activism in Indonesia. If we look back at the early emergence of the Islamic Defense Action, this social movement's discourse was disseminated through the online activism movement and various social media such as Instagram, Facebook, and Twitter. This action is claimed to be attended by millions of people from all over Indonesia. The participants also admitted that they came to the capital voluntarily to voice one thing, namely justice for Muslims and Muslims (Ahyar, 2019). The existence of the 212 Grand Reunion is seen not only as a form of unity and brotherhood of Muslims who have participated in the Islamic Defense Action in volumes. Greg Fealey sees the Action to Defend Islam as an action to revive the battle for 
primordialism and identity between "native" and "non-native" Indonesians to promote their special position among Muslims as the majority and are considered to have Indonesian political authority (Ahyar, 2019).

Looking at the analysis of agency elements, Pentadik Burke explains how agencies in the HRS mandate become a procedure that is also a function of the goals to be achieved by the agent (Griffin et al., 2019). HRS, in its rhetoric construction, wants the 212 Grand Reunion to become a tradition for every 212 Alumni, so referring back to the cause of the emergence of this movement, the 212 Grand Reunion is also one of the momentum to remind of the contradiction of primordialism and identity in Indonesia (Ahyar, 2019). This is also reminiscent of the jargon from the Action to Defend Islam "spirit 212," which was seen as propaganda jargon to strengthen Islamic identity (Ahyar, 2019) so that this second propaganda tool fulfills its use of giving grandiose sentences in order for the public to accept and agree with it without trying to check its truth (Lee \& Lee, 1939).

The third propaganda tool used by HRS is diversion or transfer. According to Lee \& Lee (1939), this propaganda tool uses prestige or authority with an honorific value in it, which can also use a position or status of honor that others consider influential or charismatic. HRS's rhetorical construction is a propaganda tool in the opening of the 212 Grand Reunion speech's opening remarks. HRS said in his speech that the former ambassador of Saudi Arabia to Indonesia, Sheikh Osama AsShuaibi, stated that HRS would be ready to be sent back to Indonesia. HRS also added that the recognition of the former Saudi Arabian ambassador to Indonesia was an extraordinary acknowledgment that there was another purpose from the Indonesian government, which made him feel blocked until now. The HRS rhetoric in it also carried out a diversion using a statement from the new Saudi Arabian ambassador, Sheikh Esam Abid Athagafi, who stated that Habib Rizieq's affairs in Saudi Arabia 284 
were currently in negotiations between high-ranking officials between the two countries between the Saudis and the Indonesian Government. This excerpt can also be explained in a diversion propaganda tool regarding alleged bans that occurred in HRS.

The rhetoric construction carried out by HRS is related to the allegation that the Government of Saudi Arabia banned him from being able to return to Indonesia during the general election for the president of the Republic of Indonesia from 2018 to 2019 (Taher, 2019). Research by Pramono (2018) explained that this is related to the initiation of HRS by FPI as of the High Imam of the FPI and the Grand Imam of the Islamic Community in Indonesia. His position is limited to the informal Islamic political leader. Becoming a formal Islamic political leader is still related to the withdrawal of the electoral system and the party system (Pramono, 2018). Thus, the development of this rhetoric has become a propaganda tool so that the public can accept diversion through the status and officials of the Saudi Arabian government itself that HRS cannot return to Indonesia from 2018 to 2019. This event explains the rhetoric he made about lies and bans by the Indonesian government towards HRS's return from Saudi Arabia.

HRS is known as a figure who is active in Indonesian politics by carrying the identity of the Islamic religious group as the High Priest of FPI. So much of the rhetoric he built in his opening speech for the 212 Grand Reunion 2019 used quotes from the Prophet Muhammad SAW. Quotation propaganda tools are intended to reinforce whether or not an action, idea, or idea is good so that the audience will follow it (Lee \& Lee, 1939). The 212 Grand Reunion, which began with the Action to Defend Islam movement at the beginning of its appearance, was intended to sue Ahok for the act of religious blasphemy during the 2016 Jakarta election campaign. As a means of political propaganda. Based on the results of Pentadic Burke's previous analysis, HRS used quotes from the words 
of the Prophet Muhammad SAW several times as in the content of the fourth mandate, which aims to arouse the enthusiasm of the Alumni of the Defense of Islam in the 212 Grand Reunion to remain committed to the struggle for justice and defending Islam. Caused by the decline in the number of participants from the 212 Grand Reunion from year to year, even though they have made national mobilization efforts (Power, 2018).

The involvement of Islamic religious groups in politics is viewed further. It shows the decentralization of apolitically autonomous ulama (Pribadi, 2018). There are two reasons why Indonesian religious leaders participate in the country's political sector. First, it shows that they can adapt to the Indonesian state's changing political atmosphere. Second, they are continuously needed by society to maintain and preserve Islamic religious values and norms (Pribadi, 2018). Islam continues to be a crucial ideological framework and social movement to mobilize. However, Islam is the subject of political debate and its object (Sproule, 1994; Pribadi, 2018). Such claims may be worrying in a democracy where the political debate should be based on rational arguments and where political correctness is seen as ruling the majority of the people (Sproule, 1994).

The fifth propaganda tool, namely plain folk or HRS's humiliation, showed his inferiority complex in opening his remarks and the fifth mandate of the opening speech for the 212 Grand Reunion in 2019. HRS expressed his gratitude and appreciation for holding the 212 Grand Reunion, which entered its third year along with his supporters. HRS called him a brother, who visited him in Mecca. A statement then follows this rhetorical construction that it is a comfort and encouragement source for HRS. The placement of humility HRS will put it at the beginning of his speech. It happened before explaining his suspicion of being banned from returning to Indonesia by using a statement of appreciation and gratitude, a label saying "brother" shows HRS trying to attract the sympathy of the audience by ensuring that figures and ideas that he will convey are good 286 
(Lee \& Lee, 1939). The next form of humiliation carried out by HRS did not explicitly use specific terms or wordings. Still, in context, it was constructed to attract sympathy from parties outside the group and its supporters. In the fifth mandate, HRS stated that no religion should be defiled, no religion should be insulted, and no religion should be abused. This statement presents the context that HRS is a figure who respects every religion. In the next statement, HRS re-emphasizes Islam's position as the majority religion of the Indonesian people and nation.

This propaganda tool's perspective also shows HRS's attitude, which aims to convince every party involved in constructing his speech to accept the HRS figure as a leader. Pramono (2018) explained that formal leaders have to prioritize their souls and behavior to maintain their leadership's image in increasing trust in the people they lead. A formal leader's effectiveness and efficiency are to put society's interests above personal and group interests to achieve the goals they aspire. Based on this view, it can then explain the purpose of using plain folk propaganda tools to construct HRS rhetoric and attract sympathy to accept then the ideas and ideas expressed in the rhetoric. However, it also shapes the acceptance of HRS figures as a leader.

HRS's propaganda tools using card-stacking or counterfeiting were often encountered in the opening of his remarks. Apart from using a propaganda tool diversion from the Saudi Arabian ambassador to Indonesia. HRS also repeatedly raised allegations that he was exiled and prevented from remaining in Saudi Arabia and unable to return to Indonesia. HRS stated that Indonesia's Government should stop the lies it deemed to be fabricated to be disseminated to the public regarding his current condition. The next form of card-stacking carried out by HRS was that he stated that he had sent reports and statements to the Indonesian embassy officials for Saudi Arabia. Still, the embassy said that HRS had never reported and did not know the news from HRS. 
This fact needs to be seen from two sides, based on the statement of Mahfud MD, the Coordinating Minister for Political, Legal, and Security Affairs of the Republic of Indonesia (Menkopolhukam), emphasizing that the government has never issued a letter of blocking against HRS (Taher, 2019). The Directorate General of Immigration at the Ministry of Law and Human Rights (Kemenhumham) also denied Rizieq's ban. Head of Subang of Immigration Public Relations Sam Fernando explained that his party had never received a request to prohibit Rizieq from entering Indonesia. The Indonesian government could not refuse HRS to return to Indonesia. This refers to Article 14 of Law Number 6 of 2011 concerning Immigration, namely Article 14 paragraph (1), where every Indonesian Citizen (WNI) cannot be refused entry into Indonesian territory (Taher, 2019).

The last form of propaganda tool used by HRS is the bandwagon, which is an invitation to agree to an idea or ideas (Lee \& Lee, 1939) by first making other propaganda constructs to convince his followers' supporters to agree with the statement. In the fifth mandate in HRS's remarks about the legal prosecution of suspected blasphemers, Rachmawati Soekarnoputri was considered to have harassed Islam by comparing the Prophet Muhammad SAW with the figure of Soekarno (FRA \& RHA, 2019). However, it can be said that the fifth mandate tends to explain the prosecution of legal justice against Rachmawati's case to Muslims but through mass mobilization nationally. This is described in the construction of the fifth mandate in his speech which contains an invitation to all Indonesian Muslims and also all Indonesian people. HRS divided its invitation into two, specifically for the 212 Grand Reunion participants and all the people of the Republic of Indonesia. However, the goal remains the same, namely the mobilization of a national movement to demand legal justice for Rachmawati, who is suspected of committing blasphemy of Islam through the poetry she delivered at Anne Avantie's fashion show. 
The context of the bandwagon in this rhetoric is constructed with the explanation of the Rachmawati case. It compared the Prophet Muhammad SAW with the figure of Soekarno, then followed by an explanation of the existence of Indonesia's formal law regarding blasphemy and an invitation to take action to defend religion if this case is not immediately handled by law enforcement in Indonesia. This construction shows that the plot raises emotions and motives for mobilizing the national religious defense action movement. Nastiti \& Ratri (2018) explaining this in emotional politics, namely emotional management for political mobilization, which means that instilling political values by Islamic organizations can occur in daily life practices through subtle forms of enforcement. In some cases, political maneuvers' emotional management is normalized, taking place in activities that cannot be separated from Indonesian society's experiences, such as implementing religious law (Nastiti \& Ratri, 2018). This process's normalization makes religious practice's political elements invisible or not explicitly (Nastiti \& Ratri, 2018). So this is why the mobilization of the movement through religious propaganda can occur because it uses messages and communications that touch people's emotions related to their daily experiences.

\section{CONCLUSION AND SUGGESTION}

\section{Conclusion}

The rhetorical construction carried out by Habib Rizieq Shihab at every 212 Grand Reunion every year has a motive for the interests of his support groups and emotional politics through religious, moral construction. This study maps and dissects the rhetorical constructs of HRS using two stages of analysis and discussion. First, using Burke's Pentadic analysis to map each context element of HRS's rhetoric in his speech at the 212 Grand Reunion 2019. 
When viewed using Pentadik Burke's rhetoric, it can be concluded that HRS has strengthened its rhetorical construction on the agent and agency elements. One of the important points at issue in HRS's rhetoric in the agent element is the encouragement of the 212 Grand Reunion participants to carry out justice and struggle to defend religion. It can be seen clearly by using data synthesis analysis in Propaganda Theory will explain the motive for mobilization to traditionalize the 212 Grand Reunion. It is also considered a symbol of reviving primordialism and identity to promote their special position among Muslims as the majority and are considered to have Indonesia's political authority (Ahyar, 2019). The political context raised by HRS through the construction of emotional politics based on religious morals is done to attract sympathy from his supporters or groups that are members of the 212 Grand Reunion to accept that he was banned, which caused him not to be able to return to Indonesia.

Furthermore, the discussion in the Propaganda Theory perspective uses seven Devices of Propaganda that are intended to find possible gaps in political propaganda in agency elements. The rhetoric in HRS's speech fulfilled the seven propaganda tools or The Devices of Propaganda, each of which had its agenda in shaping HRS figures. Then the emergence of a sense of political emotion to defend religion mobilized the people to prosecute suspected blasphemers by linking messages to the people's daily experiences. This study explains that HRS's rhetorical construction in Indonesia has a political propaganda gap that uses emotional politics by emphasizing agent and agency elements for mass mobilization nationally.

\section{Suggestion}

Kenneth Burke's theory of Dramaticism is still too broad in describing the symbols used in rhetoric. As in scene elements or scenes described as the location where the agent, action, and agency occur. 290 
However, it can still be related to the context of the rhetoric content, so that it displays symbols that correlate with the other four elements.

The next research, presumably, can use discourse analysis methods of forensic communication and Dramatic Theory. Functionalist thinking in the context of a discourse analysis method is suitable for interpreting content. Functionalist thinking sees that signs in context have a formal linguistic function in conveying certain messages.

\section{REFERENCES}

Ahyar, M. (2019). Aksi Bela Islam: Islamic Clicktivism And The New Authority Of Religious Propaganda In The Millennial Age In Indonesia. Indonesian Journal of Islam and Muslim Societies, 9(1), 1-29. https://doi.org/10.18326/ijims.v9i1.1-29.

Bachtiar, A. Y., Perkasa, D. H., \& Sadikun, M. R. (2016). Peran Media Dalam Propaganda. Jurnal Komunikologi, 13(2), 78-89.

Brummet, B. (1995). Kenneth Burke's Symbolic Trinity. Philosopby \& Rhetoric, 28(3), 234-251.

Burhani, A. N. (2016). Aksi Bela Islam: Konservatisme Dan Fragmentasi Otoritas Keagamaan. Jurnal Ma'arif, 11(2), 15-29.

Burke, K. (1968). Language As Symbolic Action: Essays On Life, Literature, And Method. Berkeley, California, United States: University of California Press.

Canel, M. J., \& Gurrionero, M. (2016). Framing Analysis, Dramatism And Terrorism Coverage: Politician And Press Responses To The Madrid Airport Bombing. Communication \& Society, 29(4), 133-149. https://doi.org/10.15581/003.29.4.133-149

Cholid, C., Choiriyati, W., \& Khazim, I. Al. (2019). Rhetoric Narrative In Prabowo National Speech 2019. Proceedings Of The First International Conference On Administration Science (ICAS 2019), 253-258. https:// doi.org/10.2991/icas-19.2019.52

Conrad, C., \& Macom, E. A. (1995). Re Visiting Kenneth Burke: Dramatism/Logology And The Problem Of Agency. 
Southern Communication Journal, 61(1), 11-28. https://doi. org/10.1080/10417949509372996

East, S., \& Miichi, K. (2019). Urban Sufi And Politics In Contemporary Indonesia: The Role Of Dhikr Associations In The Anti-'Ahok' Rallies. South East Asia Research, 27(3), 225-237. https://doi.org/1 0.1080/0967828X.2019.1667110

Facal, G. (2020). Islamic Defenders Front Militia (Front Pembela Islam) And Its Impact On Growing Religious Intolerance In Indonesia. Trans: Trans-Regional And-National Studies Of Southeast Asia, 8(1), 7-20. https://doi.org/10.1017/trn.2018.15

Foss, S. K. (2008). Rhetorical Criticism: Exploration And Practice (4th Ed.). Long Grove, Illinois, United States: Waveland Press.

FRA, \& RHA. (2019). Jejak Sukmawati: Puisi Azan Hingga Bandingkan Nabi Muhammad. Retrieved Desember 19, 2019, from cnnindonesia.com. website: https://www.cnnindonesia.com/ nasional/20191118101751-20-449219/jejak-sukmawati-puisiazan-hingga-bandingkan-nabi-muhammad

Griffin, E. (2012). A First Look At Communication Theory (8th Ed.). New York, New York, United States: The McGraw-Hill Companies.

Griffin, E., Ledbetter, A., \& Sparks, G. (2019). A First Look. AtCommunication Theory (10th Ed.). New York, New York, United States: The McGraw-Hill Companies.

Hartelius, E. J. (2008). Burke And The Bard: A Systematization Of ShakespeareanInfluencesInKennethBurke.Review Of Communication, 8(3), 303-306. https:// doi.org/10.1080/15358590802074761

Herlambang, A. A. (2019). Singgung Ahok, Berikut 4 Poin Isi Pidato Habib Rizieq di Reuni 212. Retrieved Desember 19, 2019, from ayosemarang.com. website: https://www.ayosemarang.com/ $\mathrm{read} / 2019 / 12 / 02 / 48195 /$ singgung-ahok-berikut-4-poin-isipidato-habib-rizieq-di-reuni-212

Lasswell, H. D. (1927). The Theory Of Political Propaganda. The American Political Science Review, 21(3), 627-631. http://www.tandfonline. com/doi/abs/10.1080/15205430709337006

Lee, A. M., \& Lee, E. B. (1939). The Fine Art Of Propaganda. In A. M. Lee \& E. B. Lee (Eds.), The Fine Art Of Propaganda. New York, New York, United States: Harcourt, Brace \& Company. 
Marshall, P. (2017). Conflicts In Indonesian Islam. Current Trends In Islamist Ideology, 23, 122-139.

Marshall, P. (2018). The Ambiguities Of Religious Freedom In Indonesia. The Review Of Faith \& International Affairs, 16(1), 85-96. https:// doi.org/10.1080/15570274.2018.1433588

Maya, S. (2019). Akan Datangi Reuni 212, Rizieq Shihab Masih Terkendala Visa Saudi. Retrieved Desember 19, 2019, from tirto.id. wesbite: https://tirto.id/akan-datangi-reuni-212-rizieq-shihab-masihterkendala-visa-saudi-empj

Meidinata, N. (2019). Rizieq Shihab Singgung Pencekalan Dirinya, \#BoikotBoneka212 Menggema. Retrieved Desember 19, 2019, from solopos.com. website: https://www.solopos.com/ rizieq-shihab-singgung-pencekalan-dirinya-boikotboneka212menggema-1030193

Miller, K. (2002). Organizational Communication: Approaches And Processes (3rd Ed.). Belmont, California, United States: Wadsworth.

Mojahedi, M. M. (2016). “Is There Toleration In Islam?” Reframing A Post-Islamist Question In A Post-Secular Context. ReOrient, 2(1), 51-72. https://doi.org/10.13169/reorient.2.1.0051

Murphy, M. K., \& Harris, T. M. (2018). White Innocence And Black Subservience: The Rhetoric Of White Heroism In The Help. Howard Journal Of Communications, 29(1), 49-62. https://doi.org/ 10.1080/10646175.2017.1327378

Nastiti, A., \& Ratri, S. (2018). Emotive Politics : Islamic Organizations And Religious Mobilization In Indonesia. Contemporary Southeast Asia: A Journal of International and Strategic Affairs, 40(2), 196-221. https://doi.org/10.1355/cs40-2b

Nawab, M., Osman, M., \& Waikar, P. (2019). Fear And Loathing: Uncivil Islamism And Indonesia's Anti-Ahok Movement. Indonesia, 109(106), 89-109.

Power, T. P. (2018). Jokowi's Authoritarian Turn And Indonesia's Democratic Decline. Bulletin of Indonesian Economic Studies, 54(3), 307-338. https://doi.org/10.1080/00074918.2018.1549918

Pramono, M. F. (2018). Phenomena Of Habib Muhammad Rizieq Shihab. Seminar Serantau Pendidikan Tinggi Islam (SeIPTI), 843-854. 
Prayoga, R. (2019). Panitia Berharap Habib Rizieq Hadiri Reuni Akbar 212. Retrieved Desember 19, 2019, from antaranews.com. website: https://www.antaranews.com/berita/1177392/panitia-berharaphabib-rizieq-hadiri-reuni-akbar-212

Pribadi, Y. (2018). Identity Contested: Cultural Resilience in the Midst of Islamization of Politics. Al-Jami'ah: Journal Of Islamic Studies, 56(2), 255-280. https://doi.org/10.14421/ajis.2018.562.255-280

Sproule, J. M. (1994). Channels Of Propaganda. Bloomington, Indiana, United States: EDINFO Press \& ERIC.

Suparno, B. A. (2011). Pentad Analysis Dalam Dramatisme Kenneth Burke. In A. Ishak, F. Junaedi, S. Budi HH., A. Prabowo. (Eds.), Mix Methodology Dalam Penelitian Komunikasi (Dilengkapi Dengan Aplikasi Metode Penelitian). Yogyakarta: Asosiasi Pendidikan Tinggi Ilmu Komunikasi.

Taher, A. P. (2019). Benarkah Rizieq Shihab Dicekal Saudi Atas Permintaan Indonesia? Retrieved Oktober 29, 2020, from tirto. id. website: https://tirto.id/benarkah-rizieq-shihab-dicekal-saudiatas-permintaan-indonesia-eluf

Tsikata, P. Y. (2019). A Pentadic Interrogation Of Yahya Jammeh's Economic Rhetoric Of Antiretroviral Drugs: Rhetorical Motives And Implications. Howard Journal Of Communications, 30(1), 23-37. https://doi.org/10.1080/10646175.2018.1423653

Vit, J., \& Erlangga, A. M. (2016). Human Rights Watch: Kasus Ahok Adalah "Kemunduran Bagi Demokrasi Indonesia." Retrieved Agustus 16, 2020, from vice.com website: https://www.vice. com/id_id/article/8qgg73/kasus-ahok-adalah-kemunduran-bagidemokrasi-indonesia

West, R., \& Turner, L. H. (2017). Introducing Communication Theory: Analysis And Application (6th Ed.). New York, New York, United States: McGraw-Hill Higher Education.

Widiyanto, A. (2017). Violence In Contemporary Indonesian Islamist Scholarship: Habib Rizieq Syihab And 'Enjoining Good And Forbidding Evil'. Islamic Peace Ethics, 1, 87-111. 